\title{
GAPLEK, TIWUL AND GATOT AS STAPLE FOOD IN JAVANESE BARREN AREA
}

\section{CLAUDIA JESICA, ESTHERINA CANSA, JENNICA FIDELIA, JEREMIAH IRWAN \& YOSUA WIRA ADI NUGROHO}

Nutrition and Food Technology Study Program, Faculty of Life Science, Surya University, Tangerang, Banten, Indonesia

ABSTRACT
Javanese's food consumption also affected by the area's characteristic. In some barren areas, such as
Gunung Kidul, Trenggalek, and Wonogiri, Javanese people tend to consume cassava as their staple food. They turn the
cassava into gaplek by drying the cassava under the sun, so the cassava can be stored and can be used in famine time.
Javanese culture also influenced the way of gaplek consumption. Gaplek can be processed into tiwul and gatot. Tiwul
made from chopped white gaplek that steamed, while gatot made from black brown moulded gaplek that sliced then
steamed. The unique tiwul and gatot texture affected by the gelatinization process of gaplek's starch. Tiwul usually
served as sweet snack by adding brown sugar and grated coconut flesh, or served as rice substitute by adding side
dishes.
KEYWORDS: Barren Area, Gaplek, Gatot \& Tiwul

Received: Oct 17, 2017; Accepted: Nov 08, 2017; Published: Nov 25, 2017; Paper Id.: IJHRDEC20171

\section{INTRODUCTION}

There are several barren areas in Indonesia; one of them was the area of Gunung Kidul. The area of Gunung Kidul Regency was once, a dense forest before the 1800s. The deforestation process was massively done in the 1800s and structured, when the Dutch entered Java after forcing the breaking of the Gunung Kidul area partly into the Mangkunegaran Kingdom and the Yogyakarta Kingdom (Whitten et al., 1996). Deforestation undertaken is for conversion to gardens and agriculture, as stated by Whitten et al. (1996) that, from 1940 to 1950s there were coffee plantations in the region. During the Japanese colonialism, deforestation became increasingly uncontrolled. At that time, the wood needed for the need of war and conversion to the castor bean plant, but failed because they had not understood the biophysical conditions, in the area of Gunung Kidul, which is dominated by karst (Nibbering, 1991). From then on, Gunung Kidul became barren, arid and dry, even famous for poverty from 1940s to 1970s (Sunkar, 2008). This is also in line with the results of a study, by Roche et al (1984), in which about 40 percent of the total area is severely eroded and has extremely thin soil on unterraced hillsides, where only cassava and corn can be grown. The same barren areas are also found in Central and East Java in Madiun, Banjarnegara, Trenggalek and Wonogiri.

In addition to the problem of barren land, the community in 1960 to 1970 was a poor community. According to Roche et al (1984), the gross value of food crop output is smallest in Gunung Kidul, compared with Garut and Kediri, despite the large average farm size, because the soil is poor. Cassava sales amount to about a third of total gross family income in Kediri. Cassava's predominant role as a cash crop in these two region is evidenced by the high ratios of sales to total production. Sales are smallest in Gunung Kidul, where cassava is the major calorie source. The Gunung Kidul families are poor in both relative and absolute terms, in large part because 
their land is poor. Because the soil is depleted, cassava plays a major role in farming and it becomes important food stuff, due to poverty. The welfare implications of increased cassava productivity could be substantial in Gunung Kidul. However, because, agroclimatic constraints are particularly binding in this area (Roche et al., 1984).

This condition certainly affects the food consumption of people in the barren area, by using cassava as their staple food. Javanese people in that area generally making cassava into gaplek, with the aim that can be stored longer. Gaplek is a thinly sun dried sliced cassava. Gaplek can be processed into tiwul or gatot. This review will explain the culture, method and science beyond gaplek, tiwul and gatot.

\section{JAVANESE PERPECTIVE ABOUT TIWUL AND GATOT}

Tiwul and Gatot is a cassava based traditional Javanese food. Tiwul can be considered as a rice substitute in Java specifically in barren or dry area where it's difficult to grow crops. Gaplek, the thinly sliced sun-dried cassava, can be stored for months and cooked for rice substitute as tiwul or gatot, when famine time comes.



Figure 1: Topography of Gunung Kidul

Source: BAPPEDA Gunung Kidul, 2011 http://bappeda.gunungkidulkab.go.id/publikasi/spasial/Peta-Topografi.jpg

From the point of view of Javanese people, tiwul is a kind of simple yet easy to cook dish that can help them in the hard time. The Javanese used to do everything in modestly, so they processed the cassava into tiwul modestly. From the Javanese culture's point of view, having meal is a kind of manners they usually do, so there's no need to prepare the food in fancy ways. In olden days, Javanese people utilize everything they could find in their own yard to survive from starving. They don't go to forest to hunt or fishing to fulfil their needs. They use cassava that can be found in their yard to make tiwul. At first, they sliced the cassava and sundried it, to preserve it. Then the sun-dried cassava, called gaplek chopped into coarse powder, and mixed with water then steamed. The steamed gaplek flour called tiwul, and can be eaten sweet or salty.

Some dry area of Java still eating tiwul as their staple food in the present time, also as snack for tea time in others area. Tiwul also served as tumpeng, a cone-shaped rice dish like mountain that served at syukuran, a thanksgiving event as a form of gratitude to God for the successful crops. Sometimes, tiwul served at Keraton to important guest as a nostalgic snack. 


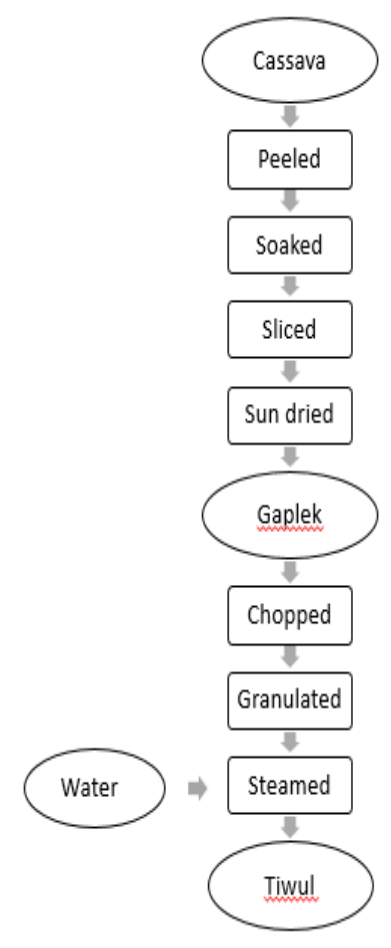

Figure 2: Flowchart Process of Tiwul Making from Cassava

\section{METHOD OF MAKING GAPLEK}

There are several step to make gaplek, the sun dried cassava. First, the cassava's skin is peeled, then the peeled cassava soaked in water for several hours. The aim of the soaking step is to reduce the hydrogen cyanide compound that naturally contained in the cassava. Hydrogen cyanide is a kind of compound that gives bitter taste. High amount of hydrogen cyanides means more bitter taste, and vice versa. According to the research, hydrogen cyanide is a toxic compound, that can lead to death if eaten in numerous amount. Hydrogen cyanide have high solubility in water and also volatile due to heat, so when cassava soaked in water, the reaction of anion cyanide $\left(\mathrm{CN}^{-}\right)$occurs. The reaction of hydrogen cyanides and water form hydronium and anion cyanide can be seen below.

$$
\mathrm{HCN}_{(a q)}+\mathrm{H}_{2} \mathrm{O}_{(l)} \rightleftharpoons \mathrm{H}_{3} \mathrm{O}_{(a q)}^{+}+\mathrm{CN}_{(a q)}^{-}
$$

Figure 3: Reaction of $\mathrm{HCN}$ with $\mathrm{H}_{2} \mathrm{O}$

The next step of making gaplek is the sun drying process. The soaked cassavas are drained then arranged in flat bamboo board, then dried under the sun for several days. After the drying process, gaplek can be stored in warehouse for months or cooked into Tiwul, by pounding the gaplek into powder then steamed after mixed with some water
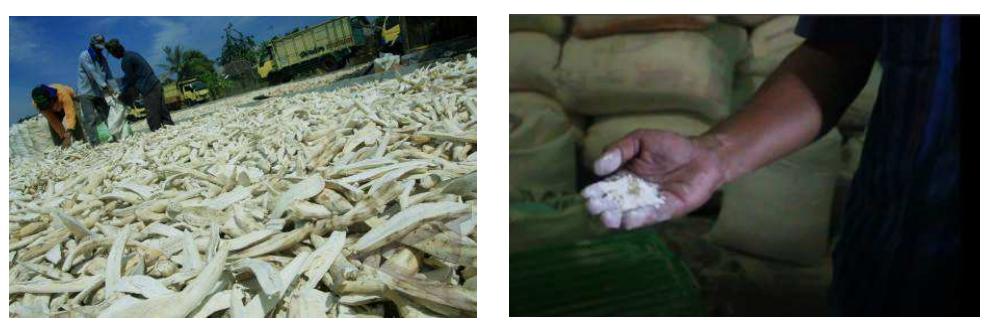

Figure 4: Gaplek 


\section{METHOD OF MAKING TIWUL AND GATOT}

The difference between tiwul and gatot derived from the gaplek's type used. White gaplek could be made into tiwul, while moldy and black-brown gaplek made into gatot. The moldy and black cassava is caused by the appearance of fermented fungus. In the beginning, gaplek is stored during the humid and mildewy rainy season. Gaplek used for the making of gatot should be soaked first to provide a chewy texture.

Traditionally, gaplek that will be processed into tiwul must be made into flour by chopping. The tool to pound gaplek called lumpang, in the form of mortar and pestle, which is also used to mash rice, corn, and other agricultural products. The mortars are usually made of wood or stone. The shape of a rectangle is, measuring about $80 \mathrm{~cm} \mathrm{x} 0.70 \mathrm{~cm} x$ $60 \mathrm{~cm}$, with a hole in the centre of a circle with about $30 \mathrm{~cm}$ in diameter. The hole depth is about $30 \mathrm{~cm}$, with the diameter getting smaller. Pestle is a heavy and hard wood with a diameter of $10 \mathrm{~cm}$, length $2 \mathrm{~m}$, and a handle in the middle of the pestle.

Gaplek that has been pounded, will be sifted by using tampah. Tampah is a bamboo webbing that is dense and smooth, arranged into a circle with a diameter of $70 \mathrm{~cm}$. The process of sifting cassava flour requires high skills. At first, pounded gaplek was placed in tampah. Then, the tampah is shaked repeatedly in circular motion, until rough cassava collected in the middle, so can be taken to be pounded again. Tampah is shaked up and down very quickly, until the gaplek flour accumulates below and moves toward the back. While the grains are still roughly above and move forward which is then poured into another container to be pounded again. This process is done continuously until obtained fine gaplek flour. Furthermore, this fine cassava flour is watered, until it is cloted and re-crushed manually. This process is still done in tampah. The coarse gaplek grain crushed by hand, until the whole flour turn into fine granulated flour, then it ready to be steamed.

In steaming, starch granules in gaplek flour will swell and absorb water easily. This process is often called gelatinization. Gelatinization depends on the starch constituent in a food ingredient. Starch is the main component forming tiwul texture, that is sticky and clotted. The main components of starch are amylose and amylopectin. The difference between amylose and amylopectin is the structure and the branched chains. Amylose has smaller structure and no branched chains meanwhile, amylopectin has bigger structure and highly branched chains. Cassava starch contains $17 \%$ of amylose and $83 \%$ of amylopectin. In steaming process, amylopectin stretches and the hydrogen bond get cut off. The higher temperature, the more hydrogen bond that is cut off (or disconnected) and it allows more water to be absorbed into the starch granules (Charles et al., 2005). In this process, the amylose molecules are released into the water phase that covers the granules so that the starch granules structure becomes unfold and makes more water absorbed. This reaction caused the granules swollen and the granules' volume increased. Water molecule will make hydrogen bond with sugar hydroxyl group from amylose and amylopectin. Free water outside granules will be reduced, and the released amylose will increase. This mechanism explains the texture of the tiwul made after the steaming process of gaplek flour. From the research that has been done by Immaningsih (2012), gaplek flour will be perfectly gelatinated in temperature 69,59 ${ }^{\circ} \mathrm{C}$. Gaplek flour has more viscosity and fastest time to gelatinized than any other flour. Faster gelatinization is caused by the higher amylopectin in gaplek flour that make tiwul swollen faster.

Tiwul can be saved in long time after steamed, by redrying the tiwul itself. To cook the dried tiwul into tiwul again, the dried tiwul need to be soaked in water to fasten the steaming process. High quality gaplek flour has clean white 
colour and unique scents. Low quality gaplek flour has dark brown colour, caused by soil after the unclean washing process. Some low quality gaplek also has grey colour which caused by the formation of moulds because of incomplete drying process. Gaplek flour will change colour into light brown after steamed. Tiwul will have the aromatic scent, sweet taste, and the soft texture. Tiwul can be served with some brown sugar and grated coconut flesh as sweet snack, or as rice substitutes, by serving tiwul with some side dish, such as chicken, tempeh, tofu, or sambal.

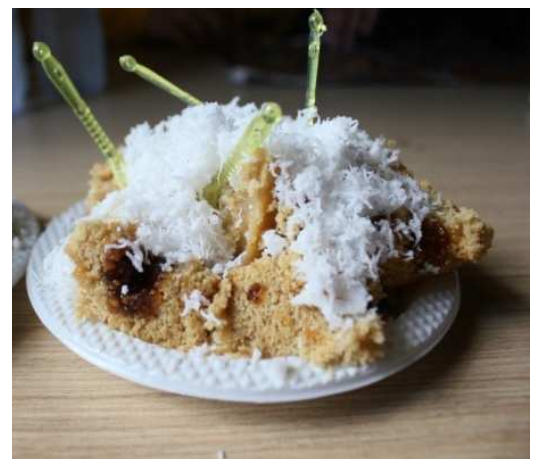

Figure 5: Tiwul

Gatot is made from the low quality gaplek, that have grey or black colour. The moulded gaplek, first soaked in water for 24 hours, then sliced into smaller pieces. The soaked black gaplek then steamed to gelatinize the starch. Then the steamed gatot served with some sugar, salt, and grated coconut flesh. Gatot usually consumed as sweet snack in tea time.

\section{NUTRITIONAL VALUE OF TIWUL}

Tiwul has similar nutritional value as rice. Rice is well-known as Indonesian staple food, that rich in carbohydrate and provides high energy. In 100 gram of white rice, there are 2,1 gram of protein, 0,1 gram of fat, 65-70 gram of carbohydrate, less than 1 gram of sugar, and other vitamins and minerals, such as 0,5 milligram of iron. While in 100 gram of Tiwul, there are 1,5 gram of protein, 0,7 gram of fat, 80 gram of carbohydrate, 1-2 gram sugar, and various vitamins and mineral such as 1,9 milligram of iron (Djuwardi, 2009). The nutritional value perspective, Tiwul has a higher carbohydrate content than white rice, but has higher content of fat, sugar, and iron. We can say that Tiwul can be used as rice substitutes because it has similar nutritional value as white rice.

Table 1: Nutritional value of Tiwul

\begin{tabular}{|l|c|c|}
\hline Nutrition Content per 100 gr & Tiwul & Rice \\
\hline Protein $(\mathrm{g})$ & 1,5 & 2,1 \\
\hline Carbohydrate $(\mathrm{g})$ & 80 & $65-70$ \\
\hline Fat $(\mathrm{g})$ & 0,7 & 0,1 \\
\hline Ash $(\mathrm{g})$ & 3 & 3 \\
\hline Iron $(\mathrm{mg})$ & 1,9 & 0,5 \\
\hline
\end{tabular}

\section{CONCLUSIONS}

Tiwul and gatot usually consumed as staple food in barren Javanese area until now, because the soil characteristic that dry and arid. Tiwul and gatot made from sun-dried cassava called gaplek. Tiwul is simple yet easy dish that can be cooked in famine time. From the Javanese people's perspective, tiwul is a simple dish. This perspective affected by Javanese culture that very simple in living. Tiwul and gatot, especially tiwul can be substitute for rice for Javanese people in barren area. It is because, tiwul has a higher carbohydrate content than rice, and also higher in fat, sugar, and iron. 
Tiwul can be consumed as a sweet snack or as rice substitute by adding side dish. To summarize, tiwul and gatot can be consumed as staple food in Javanese barren area because, its nutritional value that similar to white rice.

\section{REFERENCES}

1. Brown, A. (2007). Understanding Food Principle and Preparations Third Edition. Thomson Learning Inc.

2. Charles, A., Chang, Y., Ko, W., Sriroth, K and Huang, T. (2005). Influence of Amylopectin Structure and Amylose Content on the Gelling Properties of Five Cultivars of Cassava Starches. Journal of Agricultural and Food Chemistry 2005, 53, $2717-2725$.

3. Djuwardi, Anton. (2009). Cassava, Solusi Pemberagaman Kemandirian Pangan. Jakarta: PT Gramedia Widiasarana Indonesia.

4. Immaningsih, N. (2012). Gelatinisation Profile Of Several Flour Formulations For Estimating Cooking Behavior. Penel Gizi Makan, 35(1): 13-22

5. Nibbering JW. (1991). Hoeing in The Hills: Stress and Resilience in Upland Farming System in Java. Doctoral dissertation. Department of Human Geography, The Australian National University.

6. Sunkar A. (2008). Sustainability In Karst Resources Management: The Case of the Gunung Sewu in Java. The University of Auckland.

7. Tako, M., Tamanki, Y., Teruya, T., and Takeda, Y. (2014). The Principles of Starch Gelatinization and Retrogradation. Food and Nutrition Sciences, 5, 280-291.

8. Roche, F., Falcon, W., Jones, W., Scott, R., John, A., and Gerald, C. (1984). The cassava economy of Java. Stanford: Stanford University Press.

9. Whitten T, Soeriaatmadja R.E, \& Afiff S.A. (1996). The Ecology of Java and Bali. Singapura: Periplus. 